\title{
Publisher Correction to: COVID-19: interpreting scientific evidence - uncertainty, confusion and delays
}

Julian W. Tang

\section{Correction to: BMC Infect Dis (2020) 20:653 \\ https://doi.org/10.1186/s12879-020-05387-8}

Following publication of the original article [1], the author identified three errors in the article body:

- The typo "SARS-CoV-12,003", should be written as 'SARS-CoV-1, 2003':

i. in the 1st page, right-hand column, 2nd paragraph and

ii. in the 2nd page, right-hand column, 4th paragraph;

- In the last paragraph "SARS-CoV-2, 2003" should be written as 'SARS-CoV-1, 2003'.

The typo has been updated above and the original article [1] has been corrected.

The publisher apologizes for the inconvenience caused to the author and readers.

Published online: 23 September 2020

\section{Reference}

1. Tang JW. COVID-19: interpreting scientific evidence - uncertainty, confusion and delays. BMC Infect Dis. 2020;20:653 https://doi.org/10.1186/s12879-02005387-8.

The original article can be found online at https://doi.org/10.1186/s12879020-05387-8.

Correspondence: jwtang49@hotmail.com

Department of Respiratory Sciences, University of Leicester, Leicester LE1 7RH, UK

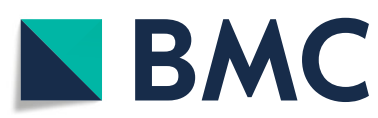

Ready to submit your research? Choose BMC and benefit from:

- fast, convenient online submission

- thorough peer review by experienced researchers in your field

- rapid publication on acceptance

- support for research data, including large and complex data types

- gold Open Access which fosters wider collaboration and increased citations

- maximum visibility for your research: over $100 \mathrm{M}$ website views per year

At $\mathrm{BMC}$, research is always in progress.

Learn more biomedcentral.com/submissions 